\section{Group science}

(T) he very earliest scientific societies were formed in the 17th and 18th centuries," Jane Maienschein, a historian and philosopher of science and Director of the Center for Biology and Society at Arizona State University, told the JCI. Maienschein's work enables her to provide a background and context for understanding the reasons for the formation of such associations as well as their evolution and development into today's myriad scientific societies. These original societies, Maienschein explained, "were formed so that people could come together and talk about what was then the new thing - science or natural philosophy." According to Maienschein, members of these societies wanted to be seen as part of the movement toward a more logical way of thinking as well as conversant with the latest developments in scientific fields.

The first of these scientific societies was the Accademia dei Lincei (the Academy of the Lynx), which was formed in 1603 and included Galileo as a member. Maienschein notes that the Accademia dei Lincei was a small group that was relatively short-lived, as it was focused around specific individuals and patrons. After this, she said, there followed "in short succession, French and English and other societies coming along ... The French and English Royal Societies are important. The Royal Societies are advocated, supported, and chartered by the king. And they start to have projects." The types of endeavors supported by these societies included ventures like determining the size of the earth, for which members needed to travel to distant parts of the world. "They do big projects. It's big science," Maienschein said.

These projects were undertaken for a number of reasons. "If you can, based on reason, understand and thereby control more of the way the world works, you're going to be in the strongest position. So there is very much of a national interest to this," Maienschein explained, but added, "Some of it is curiosity driven, especially by the scientists ... they get together and they have demonstrations and they learn about, for example, the latest in electricity or in magnetism.” But Maienschein noted that even in the more gee-whiz types of studies, there was still a sense that scientists could perhaps use these findings to aid the people in their countries.
As the 19th century came to a close, however, things began to change. "Lots of things happened at the end of the 19th century, including world economic changes eventually leading to World War I. But there is an excitement about science and progressivism that comes with a new century," Maienschein said, "and this push toward progressivism, toward science, towards an interest in the profession of science, and of scientists and engineers both who will use science to give us knowledge and make the world a better place. So by the end of the 19 th century there is the idea of the profession of science - that there are people actually being employed doing science. And those professionals wanted to set themselves off from amateurs. So that the professional natural historian or the professional astronomer, who is actually in the university and doing research, is separated off and has a club or a group that says, 'yeah, science is important but also being a professional is important."” The result, Maienschein said, "is the rise of the professional scientific society that is specifically focused on that profession. You get more and more specialized groups who want to set themselves off from others but also network, learn from each other, share with each other. And this is the context that we have been working in since - the rise of these professional societies."

Today's diverse range of scientific societies can and do fill a variety of needs for scientists. Bruce Alberts, president of the 141-year-old National Academy of Sciences (NAS), told the JCI that "a lot of the work that scientific societies do is make sure that there is funding for their area. That's a natural function. And that is an easy way to get people's attention, because they need resources to just do their work."

More importantly, Alberts believes, "Scientific societies can set standards for their scientists, try to look at bigger issues than simply where am I going to get my next grant and where do I publish my next paper.”

Alberts calls this arena of activity for societies the "policy for science." He notes that scientific societies "should have a major role doing for their group of scientists the kind of things that the academy tries to do for science more broadly, that is ask what the standards are for the discipline; how can we make our discipline more effective; what about [the] next generation of scientists? All the issues of maintaining the science in a healthy and productive state require active management. It doesn't happen spontaneously. A lot of things just get set by inertia." Alberts explained that, for example, the NAS is currently looking at what kind of courses are required for entry into medical schools, noting that many of these requirements were set $30-40$ years ago and have not been investigated since.

The NAS is different from most societies: it was signed into being by President Abraham Lincoln in 1863, has a charter that directs the society on what it needs to accomplish, and must answer to the government. Thus, unlike most scientific societies, the NAS is not self-directed, and it generally takes on more broad-stroke type initiatives for science as a whole. Alberts thinks that the self-directed scientific societies should play a similar type of role - that of exploring the broader issues that fall within their own disciplines.

Leonard Zon, Professor of Pediatrics at Harvard Medical School, is currently president of two different scientific societies, the 96-year-old American Society for Clinical Investigation (ASCI) and the 2-year-old International Society for Stem Cell Research (ISSCR). He also feels that scientific societies have a very important role to play in the scientific world. Zon told the JCI, "Each society is going to have [its] own separate goals. The major goal for ASCI has to do with mentorship and

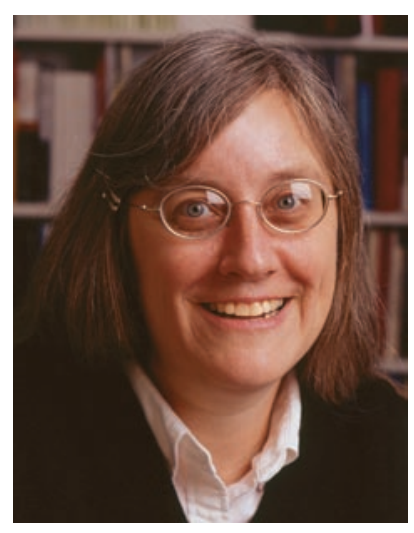

Jane Maienschein: "A challenge for societies is how do we keep from becoming societies of the elite; how do we get the advantages that come with diversity?" 


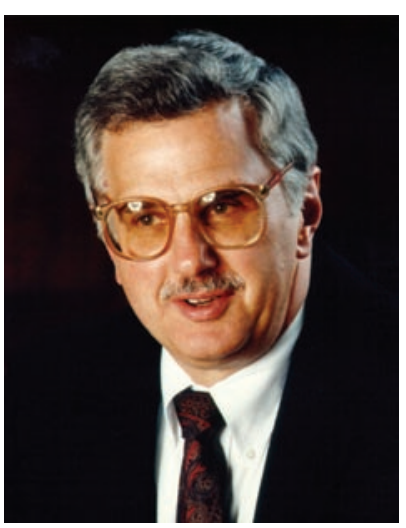

Bruce Alberts: "Our scientists need to be drawn out; we need some more public service focus."

[paving] the way for physician-scientists to have successful careers."

Zon explained that, while in the past the career path of physician-scientist had been a popular one, in the last decade or so there has been a marked decline in students considering this an optimal career choice. The importance of the physicianscientists is in their capacity, given their unique positions that straddle both the clinic and the bench, to facilitate the translation of basic research into clinical application. "It seems," Zon said, "if anything, there has been more of a separation or a schism between the physicians and the scientists. So to maintain this pool of physician-scientists requires a coordinated effort and that's what the ASCI can do."

To accomplish this task, Zon said, "My mission for this year was trying to engage a group of young scientists who have NIH K08 awards, which are the physicianscientist awards." As part of this effort, ASCI has developed a series of mentoring programs for K08 scientists that will take place at the society's annual meeting, where senior physician-scientists will talk to them about working in the lab, writing grants, and even dealing with family issues that can arise for physician-scientists.

In addition, Zon said, "What we have done is put together a really good program for the meeting that includes a few Nobel Prize winners who are going to discuss particularly the impact of their basic biological findings to clinical medicine."

"For the ISSCR," Zon said, "we had three major goals when we started this society. One was to bring scientists together from diverse fields who work on various stem cell populations, from embryonic stem cells to different organs, the [second] was to educate the public, and [the third one was] to tackle some of the ethical issues." These last two goals are geared less toward policy for science and more toward science for society.

Maienschein told the JCI that the earliest societies did play a role in educating the public. "Those groups of people came together to support public education through establishing museums, which became places that had public events and public demonstrations of cool things like electricity."

The oldest extant biological society, the Linnean Society of London, founded in 1788 , for example, does a great deal to support public education, including promoting membership to anyone with an interest in the biological sciences.

This society began in much the same way that most of the earliest societies described by Maienschein did. The original members, according to Adrian Thomas, executive secretary of the society, "were primarily gentlemen scientists with interests in natural history. Many would have been medical doctors." He explained that today "most members are professional scientists based at universities, schools, research establishments, botanical gardens or museums, especially the Natural History Museum." Thomas added that "anyone with a serious interest in natural history can join and the membership includes bankers, gardeners, diplomats, and historians. Council members are happy to nominate anyone who does not already know a Fellow who can propose them.”

This long-lived society provides additional benefits to the public by making all of its meetings open to anyone who cares to attend them. Thomas said further that "the Society is developing a program for school teachers and is raising money to put detailed images of Linnaeus's collection and the Smith Herbarium online."

While the importance of scientific societies for the health of science and for promoting the education of the public is clear, in a world where the number of societies is burgeoning, remaining a vital part of that process holds specific challenges for each society.

The Linnean Society of London has survived for over 200 years. To do so, Thomas told the JCI, "the Society has to use different methods to reach its target audience and to focus on issues in fields such as systematics, taxonomy, conservation, science policy and the history of science, which are of interest to the majority of biologists." He said the challenges he sees for societies today are "to be inclusive and offer something to the general public as well as established scientists; to maintain their unique historical character whilst being relevant to modern scientists, particularly the younger ones; to persuade government to use scientific expertise and to create an atmosphere in which disinterested science can flourish; to encourage a fruitful exchange between the arts and science."

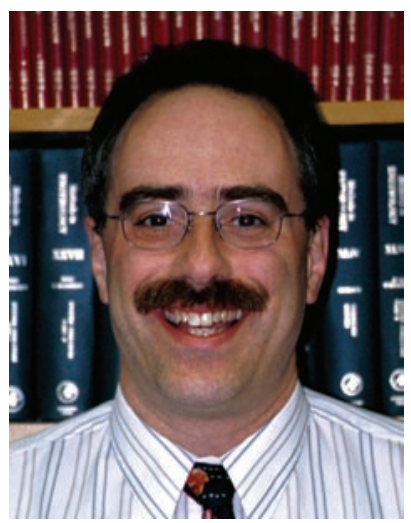

Leonard Zon: "Societies need to deliver a very clear message to their members as well as to the public."

Zon agrees that it is essential to keep membership engaged. "People will only join a society if there is value in joining that society. It's a little bit easier for something like the ASCI, where it is an honorary society, so it is an accomplishment to get in. But with some of these other societies, you are trying to keep people engaged and communicative and creating a community essentially, and that requires a lot of attention and leadership.”

Maienschein notes, "There is a feeling of belonging that comes from being in an established society, whether it is an old one or a new one. So the grad students and post-docs will typically think carefully about what they can afford to join, and may decide not to join in the societies that don't serve their purposes. But most will fairly certainly decide they want to belong to something. There is something about the feeling of connecting with other people ... that takes people beyond themselves. And that is good."

\section{Laurie Goodman}

